\title{
The Strategic Role of Healthcare Professionals in the Battle Against COVID-19: Do We Really Need Help from Community Pharmacists?
}

\author{
Kashif Ali $^{1}$, Mehwish Wajdi ${ }^{2}$ and Osama Al Quteimat ${ }^{3}$ \\ ${ }^{1}$ Department of Pharmacy Practice, Dow college of Pharmacy, Dow University of Health Sciences, Karachi, Pakistan \\ ${ }^{2}$ Department of Pharmaceutical Chemistry, Federal Urdu University of Arts, Sciences and Technology, Karachi, Pakistan \\ ${ }^{3}$ Department of Pharmacy services, Cleveland Clinic, Abu Dhabi, United Arab Emirates
}

\begin{abstract}
Wuhan, the capital of China's Hubei province, was recognised in December 2019 as the centre of an outbreak of an unknown originator of pneumonia. Intense concentrations of illness spread throughout China and, ultimately, globally. Consequently, on $7^{\text {th }}$ January, 2020, Chinese researchers identified a case of severe acute respiratory syndrome coronavirus (SARS-CoV-2) in an affected person in Wuhan as the cause. Symptoms of SARS-CoV-2 vary from mild (fever, dry cough, difficulty in breathing, and pain in muscles) to severe (acute respiratory distress syndrome [ARDS\}, azotemia or acute renal failure, ventilation associated pneumonia [VAP], and shock from sepsis). In a multidisciplinary team, pharmacists play a strategic role as medical healthcare professionals in restricting the dissemination of SARS-CoV-2 and can serve as sentinels in their communities to control and counteract this epidemic domestically.
\end{abstract}

Key Words: SARS-CoV-2, Community pharmacists, Frontline healthcare workers.

How to cite this article: Ali K, Wajdi M, Quteimat OA. The Strategic Role of Healthcare Professionals in the Battle Against COVID-19: Do We Really Need Help from Community Pharmacists?. J Coll Physicians Surg Pak 2021; 31(JCPSPCR):CR109-CR111.

On the front lines, many physicians and other allied healthcare professionals (HCPs) are fighting the SARS-CoV-2 epidemic. The pharmacists are one of the most approachable multidisciplinary HCPs in their community, raising awareness about the disease by sharing information, suggesting preventive measures, and providing counselling. The pharmacists also play a significant role in stopping the spread of SARS-CoV-2 because they provide vital need-based medications and can convince suspected SARS-CoV-2 patients and theirfamilies to wear surgical masks. Additionally, the pharmacists must be cautious of and alert to their visitors' history of travel from or to international high-risk countries and their contact with others. ${ }^{1-6}$ Pharmacists should instruct people with potential SARS-COV-2 infection to follow social distancing, abstain from close contact, avoid overcrowded areas, and practice a preventive distance of at least $2 \mathrm{~m}$ from others. They should encourageindividuals to practice adequate and frequent hand-hygiene and explain techniques that can be used to minimise infection, such as sneezing and coughing into tissue paper, disposing off the tissue paper swiftly, and avoiding touching one's facial tzone (nose, eyes and mouth) pre-and post-washing of hands. ${ }^{3}$

Correspondence to: Dr. Kashif Ali, Department of Pharmacotherapy, Dow University of Health Sciences, Karachi, Pakistan

E-mail: kashif.ali@duhs.edu.pk

Received: October 20, 2020; Revised: December 22, 2020;

Accepted: July 08, 2021

DOI: https://doi.org/10.29271/jcpsp.2021.JCPSPCR.CR109
Community pharmacist (CP) is the frontline member of healthcare team to respond to queries and suggests over-the-counter (OTC) medications and refers the patients that require clinical care (IV cannulation, IV drug administrations) and hospitalisationon time. $\mathrm{CP}$ also provides the pharmaceutical care to community during the SAR-COV-2 pandemic by coordinating with pharmaceutical companies, drug distributors to make sure the availability of demanded medicines. ${ }^{7} \mathrm{CP}$ educates the community about the prevention of infection and its management, by displaying drafted professional guidances to pharmacists and pharmacies (Table I).

Following announcements in the news about rapid spread of SARS-CoV-2, CPs were forced to confront a severe shortage of hand sanitisers and surgical masks. Soon after the first diagnosed case of SARS-CoV-2, the distribution of numerous disinfectants for instance, isopropyl alcohol, hydrogen peroxide, and chloroxylenol (Dettol) - became limited in the market, and the remaining stocks of such products were hidden by suppliers, who steeply raised the costs. This overwhelming demand and deficit imbalance greatly increased the susceptibility of individuals to disease. ${ }^{8}$ The community pharmacy is an ideal outlet for securing the stock of the aforementioned products. It is also important for CPs to have a deep understanding of medical masks, as there are numerous types of facial masks available in the market - for instance, surgical face masks, N95, and so on - and an inappropriate selection, unable to prevent the transmission of the virus, would hinder the community's sense of security and protective pathways. 


\begin{tabular}{l} 
Table I: COVID-19 10-steps guidance for pharmacy teams. \\
\begin{tabular}{|l|l|}
\hline 1 & $\begin{array}{l}\text { Pharmacy display: Need to have standee at the entrance of community pharmacy suggesting if anybody has signs or } \\
\text { symptoms of novel SARS-CoV-2 to call the designated helpline for guidance. }\end{array}$ \\
\hline 2 & $\begin{array}{l}\text { Proper hand washing: providing hand sanitizers at the pharmacy counter, enforcing hand washing with or without soap } \\
\text { frequently for minimum } 20 \text { seconds. }\end{array}$ \\
\hline 3 & $\begin{array}{l}\text { Self-quarantine: Self-quarantine for a minimum of } 14 \text { days or as appropriate according to local guidelines in patients with } \\
\text { SARS-CoV-2 symptoms including fever and cough }\end{array}$ \\
\hline 4 & $\begin{array}{l}\text { Keep distance: Keep a distance of 1-m between patients and yourself while receiving and filling out prescriptions. Consider } \\
\text { limiting the entrance of patients in order to reduce direct contact. }\end{array}$ \\
\hline 5 & $\begin{array}{l}\text { Wearing mask: Always wear a mask while dealing with patients and frequently change masks whenever needed. } \\
\text { Handling of prescription: Wear single-use gloves in the pharmacy. Make sure to dispose off your gloves when you deal }\end{array}$ \\
\hline 7 & $\begin{array}{l}\text { Handling mobile phones: Encourage patients to rub or disinfect mobile phones with alcohol swab, before they use it. } \\
\text { Handling computers or cash: Disposable gloves should be used while dealing with the cash and it should be disposed off } \\
\text { appropriately. Handling of cash and medicines should not be done by same person. }\end{array}$ \\
\hline 9 & $\begin{array}{l}\text { Area sanitation: All premises in the pharmacy, for instance, telephones, shelving and medicines packaging should be } \\
\text { disinfected regularly. }\end{array}$ \\
\hline 10 & $\begin{array}{l}\text { SARS-CoV-2 Testing: will only be done if: } \bullet \text { Travelled abroad recently } \bullet \text { Travelled to rural or urban city and revealing COVID-19 } \\
\text { symptoms } \bullet \text { Direct contact with someone who has travelled abroad recently } \bullet \text { Anyone showing COVID-19 symptoms: fever, } \\
\text { persistent cough and shortness of breath. }\end{array}$ \\
\hline
\end{tabular} \\
\hline
\end{tabular}

Home-made masks made from simple materials, which only cover the face but cannot prevent the transmission of bacteria and virus particles, are also available. However, the performance of surgical masks exceeds that of home-made masks with respect to the efficiency of bacterial filtration, penetration resistance, and differential pressure as specified by guidelines of the World Health Organization (WHO) ${ }^{9-11}$ The dissemination of SARS-CoV-2 has increased patients' questions regarding masks; in order to fulfill the demand for answers, CPs have become incredibly valuable professionals when recommending rational choices and managing the appropriate inventory of medical face masks for predetermined purposes. Additionally, community pharmacies should set standard costs for surgical masks in order to halt the rising prices. ${ }^{1,2}$

As far as the management of the epidemic is concerned, no specific recommended treatment options for SARS-COV-2 are available. ${ }^{12,13}$ The supportive care depends on the clinical symptoms of patients. However, treatments using analgesics, hydration, and oxygen therapy have been suggested, and, in cases where bacterial infections alongside SARS-CoV-2 are identified, antibiotics are recommended as well. ${ }^{3,4}$ Some evidence suggests the use of chloroquine phosphate in the treatment of SARS-CoV-2, and trials have revealed promising results regarding its efficacy in managing SARS-COV-2 with pneumonia.

Miscommunication occurred during US President Donald Trump's press conference speech on $19^{\text {th }}$ March, 2020, in which he endorsed the promising results of chloroquine phosphate and mistakenly announced that the Food and Drug Administration (FDA) had recommended the medication for SARS-CoV-2 treatment. Many individuals then began to take chloroquine phosphate as a prophylactic agent despite the lack of evidence of its use, resulting in cases of chloroquine toxicity. ${ }^{13}$ In future, CPs should ensure that they are up-to-date in their knowledge of existing guidelines, resist dispensing chloroquine phosphate or other suspect treatments, and raise awareness of misconceptions. ${ }^{13}$

In summary, CPs as an integral member of HCP team play a strategic role not only as a first responder but also coping with the shortages of essential medicines during the pandemic of SARS-CoV-2 and providing supportive therapy for minor ailments to minimize the visits to the hospitals and clinics.

\section{CONFLICT OF INTEREST:}

The authors declared no conflict of interest.

\section{AUTHORS' CONTRIBUTION:}

$\mathrm{KA}$ : Contributed in idea designing, commentary writing. MW: Worked as co-supporter of this short communication. OAQ: Helped in writing and reviewing the short communication.

\section{REFERENCES}

1. Wang Q, Zhang Y, Wu L, Niu S, Song C, Zhang Z, et al. Structural and functional basis of SARS-CoV-2 entry by using human ACE2. Cell 2020; 181(4):894-904. doi:10. 1016/ j.cel1.2020.03.045.

2. World Health Organisation. Coronavirus. Available from: http :www.who.int/healt h-topic s/coron aviru s. Accessed 13 Feb 2020.

3. Saad MA. Pakistan's fight against the coronavirus threat. Available on: http://thediplomat. com/2020/03/pakistans-fight-against-the-coronavirus-threat/. Accessed. 2020 Apr; 5.

4. National Health Service (NHS). Novel coronavirus (COVID-19) standard operating procedure (community pharmacy), Version 1.0. 27 Feb 2020.

5. World Health Organization (WHO) Emergency Committee. Statement on the Second Meeting of the International Health Regulations (2005) Emergency Committee Regarding the Outbreak of Novel Coronavirus (2019-nCoV). Geneva: WHO; 30 January 2020. 2020; 2020http://www. 
who.int/newsroom/detail/30-01-2020-statement-on-thesecondmeeting-of-the-international-health-regulations-(2005)-emergencycommitteeregarding-the-outbreak-of-novel-coronavirus-(2019-ncov, Accessed date: 9 February 2020.

6. Jennifer N. Clinical pharmacists play active roles in coronavirus preparation efforts. Pharm Times 2020; 3.

7. ASHP. Coronavirus disease 2019 (COVID-19) resources. Accessed online on 20 Mar 2020 at http://www.ashp.org/ pharmacy-practice/resource-centers/coronavirus.

8. Information Bureau, Macao Sar Government. Press Release "Updates on New Coronavirus" on 7 February 2020. 2020; 2020http://www.gov.mo/zh-hant/news/ 317427/, Accessed date: 9 February 2020.

9. The U.S. Food and Drug Administration. Surgical Masks-Premarket Notification [51(k0) Submissions. Guidance for Industry and FDA Staff. 2018; 2018http://www.fda.gov/ regulatory- information/searchfda-guidance documents/ surgical-maskspremarket-notification-510k-submissions, Accessed date: 9 February 2020.

10. European Standards. UNE EN 14683:2019+AC: 2019. Medical Face Masks Requirements and Test Methods. 2019; 2019 http://www.en-standard.eu/une-en14683- 2019ac-2019-medical-face-masksrequirements-and-test-methods/, accessed date: 9 February 2020.

11. World Health Organization. Novel coronavirus (2019-ncov) v2 operational support \& logistics disease commodity packages. http://www.who.int/docs/default-source/corona viruse/dcp-ncov.pdf?sfvrsn=f5fe6234_4\&download= true; 2020 2019, Accessed date: 9 February 2020.

12. Information Bureau, Macao Sar Government. Press Release "The Guaranteed Mask Supply for Macao Residents Scheme" on 22 January 2020. 2020; 2020http://news. gov.mo/detail/zh-hant/N20AVJspef?14, Accessed date: 9 February 2020.

13. Covid-19: Six million doses of hydroxychloroquine donated to US despite lack of evidence BMJ 2020; 368 doi: http://doi.org/10.1136/bmj.m1166 (Published 23 March 2020) Cite this as: BMJ 2020; 368: m1166. 